\title{
Confocal laser endomicroscopy in the diagnostics of esophageal diseases: a pilot study
}

\section{Lumír Kunovský1,2, Zdeněk Kala², Radek Kroupa', Tomáš Grolich², Jiří Dolina', Milan Dastych', Jitka Vaculová', Jakub Vlažný3, Petr Moravčík², Lydie Izakovičová Hollá4,5, Petra Bořilová Linhartová4,5, Petr Jabandžiev ${ }^{6}$, Vladimir Procházka ${ }^{2}$}

'Department of Gastroenterology and Internal Medicine, University Hospital Brno, Faculty of Medicine, Masaryk University, Brno, Czech Republic

2Department of Surgery, University Hospital Brno, Faculty of Medicine, Masaryk University, Brno, Czech Republic ${ }^{3}$ Department of Pathology, University Hospital Brno, Faculty of Medicine, Masaryk University, Brno, Czech Republic ${ }^{4}$ Department of Pathophysiology, Faculty of Medicine, Masaryk University, Brno, Czech Republic ${ }^{5}$ Clinic of Stomatology, St. Anne's Faculty Hospital, Faculty of Medicine, Masaryk University, Brno, Czech Republic ${ }^{6}$ Department of Pediatrics, University Hospital Brno, Faculty of Medicine, Masaryk University, Brno, Czech Republic

Background: Probe-based confocal laser endomicroscopy ( $(\mathrm{CLE})$ is a novel diagnostic technique for endoscopy which enables a microscopic view at a cellular resolution in real-time. Endoscopic detection of early neoplasia in the distal esophagus is difficult and often these lesions can be missed. The aim of the pilot study was to obtain characteristic pCLE figures in esophageal diseases for following studies, and to evaluate the possible future role of pCLE in the diagnostics of dysplastic Barrett's esophagus (BE) or early esophageal adenocarcinoma (EAC). Methods: A review of the current literature was performed and previously published pCLE images and classifications of esophageal diseases were searched and studied first. In phase two of the pilot study patients with esophageal diseases such as reflux esophagitis, BE and EAC were enrolled and scheduled for upper endoscopy with PCLE. A healthy cohort was also included. Results: From January 2019 to July 2019, a total of 14 patients were enrolled in this prospective pilot study: 3 patients with reflux esophagitis, 4 with BE, 3 with EAC and 4 persons were included in the healthy cohort. The endoscopy with pCLE was performed and characteristic pCLE figures were obtained. The correct diagnoses based on real-time pCLE were evaluated by an endoscopist in 11 of the 14 cases $(78.6 \%)$. Conclusion: It was possible to obtain typical pCLE images of esophageal diseases during a standard cap-assisted endoscopic procedure. pCLE seems to be a feasible new technique in BE surveillance and early neoplastic lesion detection. However, more studies and data on larger number of patients are needed.

Key words: Barrett's esophagus, confocal laser endomicroscopy, esophageal cancer, esophagitis.

\section{Konfokální laserová endomikroskopie v diagnostice onemocnění jícnu: pilotní studie}

Úvod: Konfokální laserová endomikroskopie využívající sondy (probe-based confocal laser endomicroscopy - pCLE) je nová diagnostická metoda určená pro endoskopii, která umožňuje mikroskopické vyšetření na buněčné úrovni v reálném čase. Endoskopická diagnostika časných neoplastických lézí distálního jícnu není snadná a často tyto léze mohou být přehlédnuty. Cílem pilotní studie bylo získat charakteristické pCLE obrazy u onemocnění jícnu pro další studie a vyhodnotit možnou roli pCLE v diagnostice dysplastického Barrettova jícnu (Barrett's esophagus - BE) a časného adenokarcinomu jícnu (esophageal adenocarcinoma - EAC). Metody: Nejprve byl vyhledán přehled současné literatury s následným nastudováním předchozích publikací obsahující pCLE obrazy a jejich klasifikací u onemocnění jícnu. $V$ druhé fázi byli do této pilotní studie zařazeni pacienti 
s onemocněním jícnu, kteří podstoupili horní endoskopické vyšetření s pCLE. Zařazena byla i zdravá kohorta osob. Výsledky: Od ledna roku 2019 do července roku 2019 bylo vyšetřeno celkem 14 pacientů v rámci této prospektivní pilotní studie: 3 pacienti s refluxní ezofagitidou, $4 \mathrm{~s} \mathrm{BE}, 3 \mathrm{~s}$ EAC a 4 zdravé osoby. Byla provedena endoskopie s pCLE a získány charakteristické pCLE obrazy. Správná diagnóza byla endoskopistou stanovena pomocí pCLE (real-time) celkem u 11 ze 14 vyšetřených pacientů (78,6 \%). Závěr: Bylo možné získat typické pCLE obrazy u onemocnění jícnu během standardní endoskopie s využitím capu. pCLE se zdá být novou slibnou metodou k surveillance BE a detekci časných neoplastických lézí. Na druhou stranu je zapotřebí více dalších studií a dat na větším souboru pacientů.

Klíčová slova: Barrettův jícen, ezofagitida, konfokální laserová endomikroskopie, nádory jícnu.

\section{Introduction}

Probe-based confocal laser endomicroscopy ( $\mathrm{PCLE}$ ) is a new diagnostic technique for endoscopic use. PCLE provides a microscopic view at a cellular resolution in real-time. Barrett's esophagus (BE) is considered as a premalignant condition for esophageal adenocarcinoma (EAC). Although the risk of cancer progression from nondysplastic BE is quite low (0.12-0.5\% per year) $(1,2)$, patients with BE are managed with endoscopic surveillance. According to the European society for gastrointestinal endoscopy (ESGE) guidelines, the patient should undergo high-definition white-light endoscopy (HD-WLE) with targeted biopsies from every visible lesion and random four-quadrant biopsies every $2 \mathrm{~cm}$ (3).

Unfortunately, endoscopic detection of early neoplasia is difficult and these lesions can often be missed (4). Moreover, EAC risk is significantly higher in dysplastic BE and the risk increases from $6 \%$ up to $13 \%$ annually (4-6).

PCLE as a novel endoscopic technique enables real-time microscopic imaging of the mucosal tissue, and may play an important role in future diagnostics of dysplastic BE or early EAC.

\section{Methods}

A review of the current literature about $\mathrm{PCLE}$ in esophageal diseases was carried out first. Then the PCLE images from previously published articles, classifications and criteria for PCLE were studied (Miami classification for BE published by Wallace, with the addition of the description for low-grade dysplasia (LGD) by di Pietro and for high-grade dysplasia (HGD) by Gaddam (7-9).

From January 2019 to July 2019, a total of 14 patients were enrolled into this prospective pilot study. The study protocol was approved by the ethical committee of University Hospital Brno and all patients signed the informed consent. The healthy cohort consisted of volunteers from the medical students. Midazolam was used for sedation. A half dose of
Fluorescite $^{\circledast}(2.5 \mathrm{ml})$ with $8 \mathrm{ml}$ of saline solution as a contrast agent was used. The cap was placed at the end of the endoscope before the examination. During the endoscopic procedure we used the GastroFlexTM UHD confocal probes connected to a Cellvisio ${ }^{\oplus}$ system (fig. 1a, 1 b). The patients underwent a standard upper endoscopy, the esophagus and gastroesophageal junction were also carefully examined using high definition Fujifilm ${ }^{\oplus}$ endoscopes with white light endoscopy, blue light imaging (BLI), linked color imaging (LCI) and then by pCLE (fig. 2a, 2 b). Biopsies were taken from every area investigated by $\mathrm{PCLE}$, and $\mathrm{PCLE}$ videos were later

Fig. 1a, 1b. Position of the endoscopic tower Fujifilm ${ }^{\circledast}$ and the Cellvisio endoscopy system ${ }^{\circledR}$ including the laser scanning unit and display (Mauna Kea Technologies, Paris, France) during the endoscopic procedure

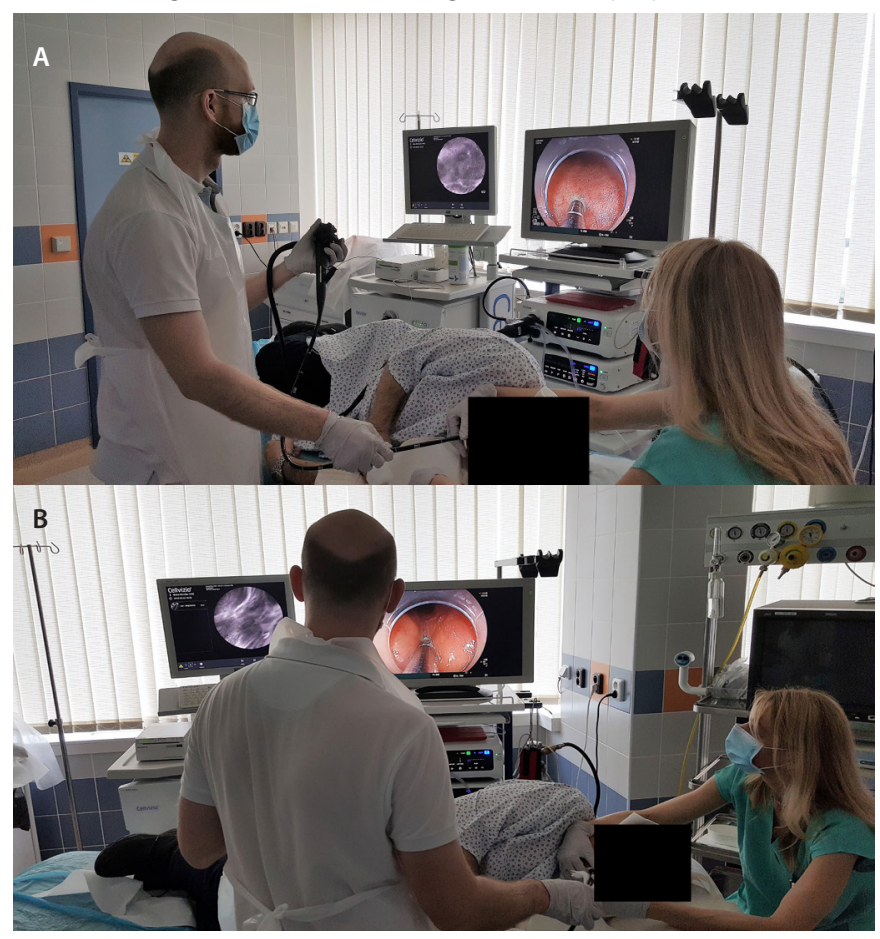

Tab. 1. Baseline characteristics of patients $(n=14)$

\begin{tabular}{|l|c|c|c|c|c|}
\hline Variable & Total $(\mathbf{n}=\mathbf{1 4 )}$ & $\begin{array}{c}\text { Healthy cohort } \\
\mathbf{( n = 4 )}\end{array}$ & $\begin{array}{c}\text { Reflux esophagitis } \\
\mathbf{( n = 3 )}\end{array}$ & $\begin{array}{c}\text { Barrett's esophagus } \\
\mathbf{( n = 4 )}\end{array}$ & $\begin{array}{c}\text { Esophageal } \\
\text { adenocarcinoma } \\
(\mathbf{n}=\mathbf{3})\end{array}$ \\
\hline Male/female & $\mathrm{M}: 10 / \mathrm{F}: 4$ & $\mathrm{M}: 3 / \mathrm{F}: 1$ & $\mathrm{M}: 2 / \mathrm{F}: 1$ & $\mathrm{M}: 2 / \mathrm{F}: 2$ & $\mathrm{M}: 2 / \mathrm{F}: 1$ \\
\hline Age (average) & 45.8 & 25.3 & 39.0 & 54.3 & 70.5 \\
\hline BMI (average) & 26.2 & 24.8 & 27.9 & 25.9 & 26.8 \\
\hline Smoking & $\mathrm{Y}: 3 / \mathrm{E}: 3 / \mathrm{N}: 8$ & $\mathrm{Y}: 0 / \mathrm{E}: 0 / \mathrm{N}: 4$ & $\mathrm{Y}: 2 / \mathrm{E}: 0 / \mathrm{N}: 1$ & $\mathrm{Y}: 1 / \mathrm{E}: 1 / \mathrm{N}: 2$ & $\mathrm{Y}: 0 / \mathrm{E}: 2 / \mathrm{N}: 1$ \\
\hline PPI users & $\mathrm{Y}: 7 / \mathrm{N}: 7$ & $\mathrm{Y}: 0 / \mathrm{N}: 4$ & $\mathrm{Y}: 2 / \mathrm{N}: 1$ & $\mathrm{Y}: 4 / \mathrm{N}: 0$ & $\mathrm{Y}: 1 / \mathrm{N}: 2$ \\
\hline Hiatal hernia & $\mathrm{Y}: 4 / \mathrm{N}: 10$ & $\mathrm{Y}: 0 / \mathrm{N}: 4$ & $\mathrm{Y}: 2 / \mathrm{N}: 1$ & $\mathrm{Y}: 1 / \mathrm{N}: 3$ & $\mathrm{Y}: 1 / \mathrm{N}: 2$ \\
\hline
\end{tabular}

$Y$-yes, $N$ - no, $M$ - male, F-female, BMI - body mass index, PPI - proton pump inhibitor, E-ex-smoker 
correlated with the histopathologic findings (by a histopathologist and an endoscopist independently, and in phase two by a histopathologist and an endoscopist together). The aim of the pilot study was to obtain basic microscopic images of a healthy esophagus, esophagitis, BE and EAC.

\section{Results}

A total of 14 patients were enrolled in the study and underwent an upper endoscopy with $\mathrm{PCLE}$, of which 10 patients were male and 4 were female. The average age was 45.8 years and the mean BMI was 26. 2. The following diagnoses were endoscopically identified and later confirmed by histopathology results: 3 patients with reflux esophagitis, 4 with BE (3 patients with intestinal metaplasia (IM), 1 patient with LGD), 3 patients with EAC and 4 persons were included in the healthy cohort. Half of the patients were current users of proton pump inhibitors, 3 patients were smokers, 3 patients were ex-smokers, and in 4 patients hiatal hernia was present among the endoscopic findings. The baseline characteristics of the patients can be seen in table 1.

The upper endoscopy examination was followed by pCLE. No adverse effects were observed after the application of the contrast agent. Videos were recorded during all of the PCLE procedures. Every video record was evaluated during the endoscopy, and then re-evaluated with a final histopathology result according to each diagnosis of reflux esophagitis, BE (IM, LGD), EAC, and also in the healthy cohort.

In a healthy esophagus we observed these PCLE images: normal squamous epithelium which appears as typical scale-like cells (fig. 3a), without the presence of inflammatory cells, sporadically intrapapillary capillary loops were also observed (fig. 3 b).

In patients with reflux esophagitis we saw columnar cells, hyperemia and inflammatory cells in the area of the gastroesophageal junction (fig. 4a), and in the squamous epithelium, stromal papillae with hyperemia in the distal esophagus (fig. 4 b).

The characteristic PCLE figures which we saw (and recorded) during the procedure in nondysplastic BE were: columnar cells and uniform villiform architecture and with dark goblet cells (fig. $5 a, 5$ b). In the patient with both BE and LGD we observed: dark non-round glands, lack of goblet cells, a sharp cutoff of darkness and variable cell size (fig. 6a, 6 b). No patient with HGD participated in our pilot study. In patients with EAC the following signs were seen: disorganization or a loss of structure, dark columnar cells with severe nuclear atypia and dilated irregular vessels (fig. 7a, 7 b).
The comparison of the PCLE images and the final histopathology figures from the biopsies taken can be seen in Fig. 3c-7c.

The correlations between the PCLE images captured by endoscopists and the definitive histopathology results are summarized in table 2. The correct diagnoses based on real-time PCLE were evaluated by an endoscopist in 11 of the 14 cases (78.6\%). The average time of pCLE examination needed to obtain a diagnosis based on PCLE images was 8 minutes.

Fig. 2. Endoscopic view in high-definition white-light endoscopy (HD-WLE) (a) and blue light imaging (BLI) (b) of nondysplastic Barrett's esophagus investigated with the confocal probe Cellvisio ${ }^{\oplus}$

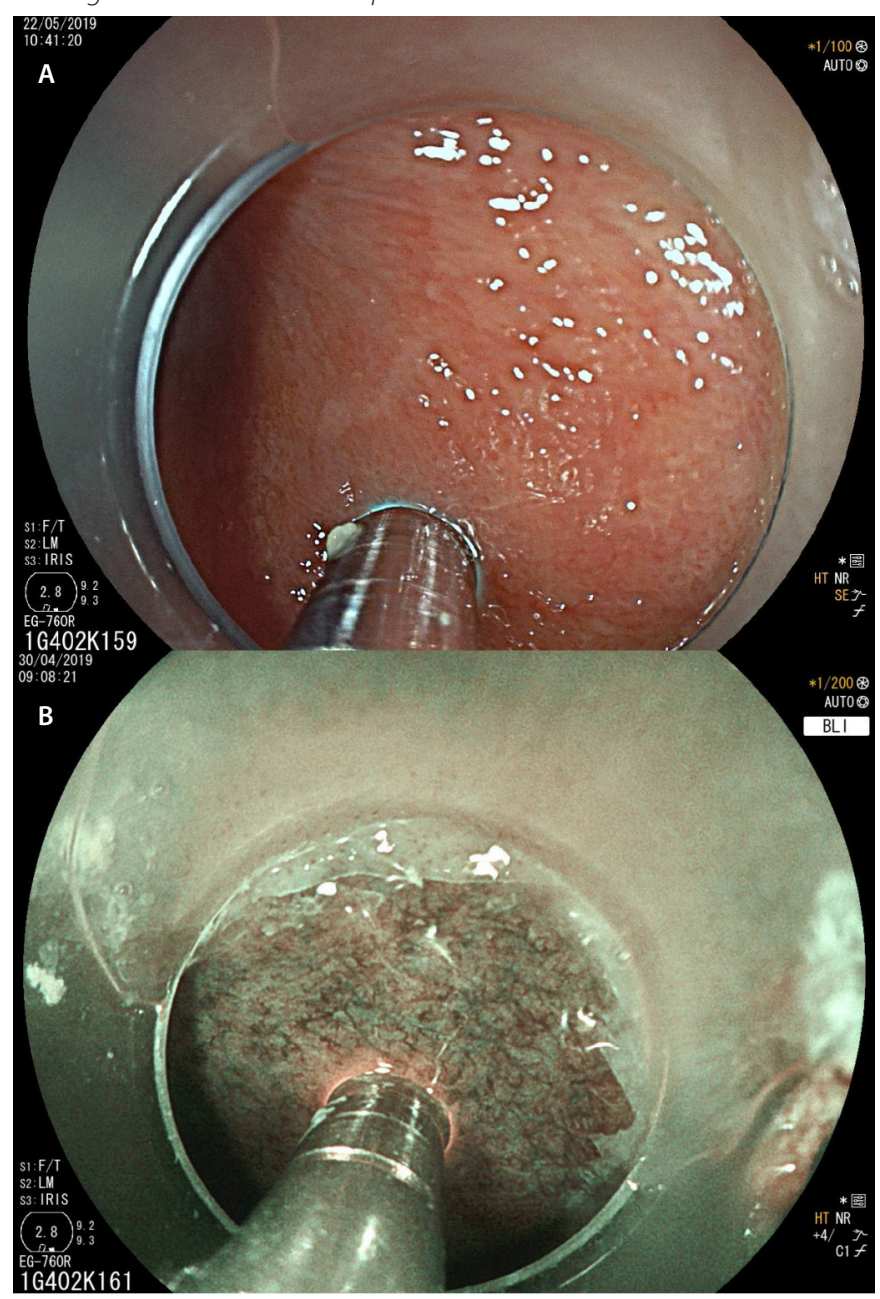

Tab. 2. Correlation between PCLE images and definitive histopathology samples

\begin{tabular}{|c|c|c|c|c|c|}
\hline Variable & Total & $\begin{array}{l}\text { Healthy cohort } \\
\qquad(n=4)\end{array}$ & $\begin{array}{l}\text { Reflux esophagitis } \\
\qquad(\mathrm{n}=3)\end{array}$ & $\begin{array}{l}\text { Barrett's esophagus } \\
\qquad(n=4)\end{array}$ & $\begin{array}{c}\text { Esophageal } \\
\text { adenocarcinoma } \\
(\mathrm{n}=3)\end{array}$ \\
\hline Histology & 14 & $\begin{array}{c}\text { Esophageal } \\
\text { squamous epithelium: } \\
4\end{array}$ & $\begin{array}{l}\text { Reflux esophagitis } \\
\text { (grade 1): 2, (grade } \\
\text { 2): } 1\end{array}$ & IM:3, LGD:1 & $\begin{array}{c}\text { Esophageal } \\
\text { adenocarcinoma: } 3\end{array}$ \\
\hline $\begin{array}{l}\text { Correct pCLE established } \\
\text { diagnoses/definitive } \\
\text { histopathology diagnoses }\end{array}$ & $11 / 14$ & $4 / 4$ & $2 / 3$ & $3 / 4$ & $2 / 3$ \\
\hline $\begin{array}{l}\text { Average time of pCLE procedu- } \\
\text { re needed to establish diagnoses } \\
\text { based on pCLE images (minutes) }\end{array}$ & 8.0 & 6.0 & 7.5 & 9.6 & 9.0 \\
\hline
\end{tabular}

pCLE - probe-based confocal laser endomicroscopy, IM - intestinal metaplasia, LGD - low grade dysplasia 


\section{Discussion}

pCLE is a novel diagnostic method used in gastrointestinal endoscopy ( $\mathrm{BE}$, gastric diseases, pancreatic cysts, bile duct structures and inflammatory bowel disease or colorectal lesions in the colon), as well as in the pulmonary and urinary systems, and even during surgical procedures $(10,11)$.

Promising data and results were gained especially for BE. One of the first prospective multicenter studies was published by Wallace et al in 2010 (7). 40 sites of BE tissue were investigated by PCLE (followed by matching biopsies) and evaluated by 11 experts in $\mathrm{BE}$, with results which suggest that PCLE has a very high accuracy for the diagnoses of neoplasia in BE.

One year later Sharma et al (12) in 2011 published another prospective multicenter study on a larger cohort of patients and with a different study design. The pCLE were examined in 101 patients with BE and the combination of HD-WLE with pCLE significantly improved the ability to detect neoplasia in BE in comparison to just HD-WLE alone.

In 2011 Gaddam et al (8) set the pCLE criteria for dysplastic BE (HGD/cancer). The study resulted in the formulation of a total of six PCLE criteria which predicted dysplasia with a good degree of accuracy. These criteria were as follows: saw-toothed epithelial surface, not easily identifiable goblet cells, non-equidistant glands, unequal size and shape of glands, enlarged cells, and irregular and non-equidistant cells. However this work did not evaluate the ability of these criteria to diagnose LGD.
Diagnostic criteria from di Pietro et al (9) in 2019 have recently been published. The best cutoff for LGD diagnosis was the positivity of any 3 of the 6 following criteria: dark non-round glands, irregular gland shape, lack of goblet cells, sharp cutoff of darkness, variable cell size, and cellular stratification

The characteristic PCLE figures we obtained were in accordance with previously published articles and classifications (in diagnosis with BE, EAC and healthy esophagus). We found just one study from Canto et al (13) in which patients with esophagitis were also investigated using PCLE. However, the aim of that study was focused on neoplastic lesion detection and there is a lack of information about pCLE images of esophagitis. In our pCLE figures we recorded columnar cells with hyperemia and inflammatory cells (in the area of the gastroesophageal junction) and squamous epithelium in the distal esophagus with stromal papillae and their hyperemia.

Early detection of dysplastic BE lesions and their treatment is a goal for the prevention of EAC progression. However, the identification and detection of these lesions can be challenging for endoscopists. In 2017, Schölvinck et al (4) published a comparative study where the detection rates of neoplastic visible lesions (HGD or early EAC) were $60 \%$ in community centers and $87 \%$ in expert centers. This supports the value of expert centers for visible lesion detection. The detection and more accurate specification of the lesion can be even higher in combination with $\mathrm{PCLE}$.

Fig. 3. pCLEview of a normal distal esophagus: a, b-normal squamous epithelium of the esophagus (typical scale-like cells), no edema or inflammatory cells; c - histopathology examination: normal squamous epithelium, haematoxylin-eosin staining 40x

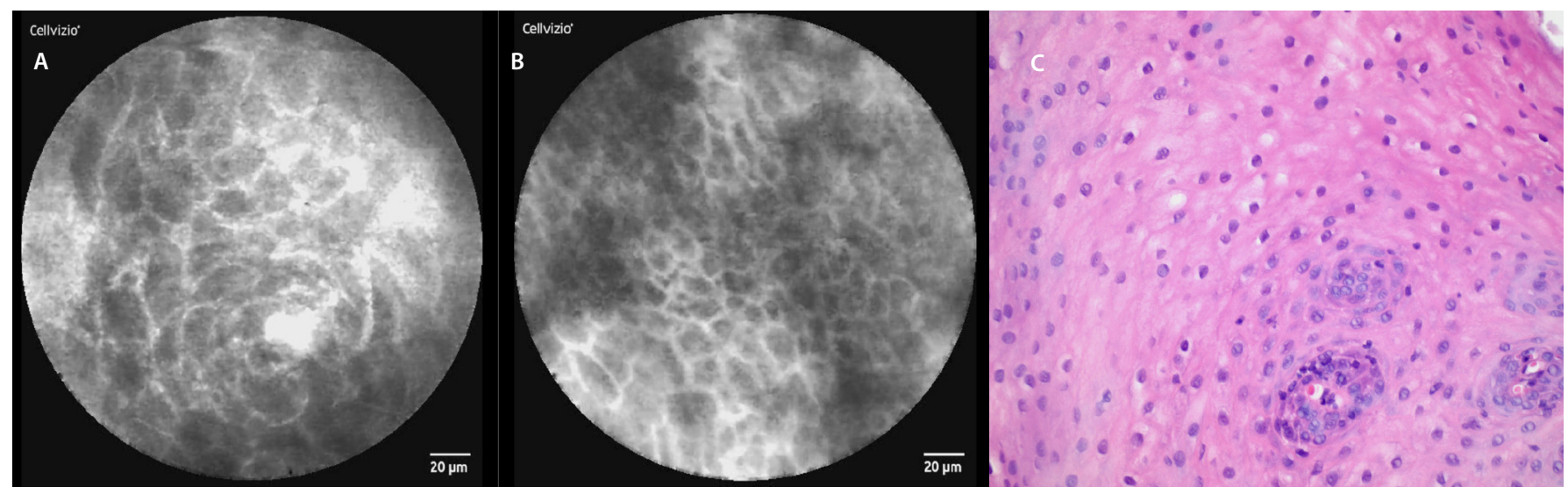

Fig. 4. pCLE view of esophagitis: a - columnar cells, hyperemia and inflammatory cells (area of gastroesophageal junction), b-squamous epithelium, stromal papillae with hyperemia; $c$ - histopathology examination: mixed acute and chronic inflammatory cells in the epithelium, basal cell hyperplasia, elongation and hyperemia of the lamina propria papillae, haematoxylin-eosin staining 40x

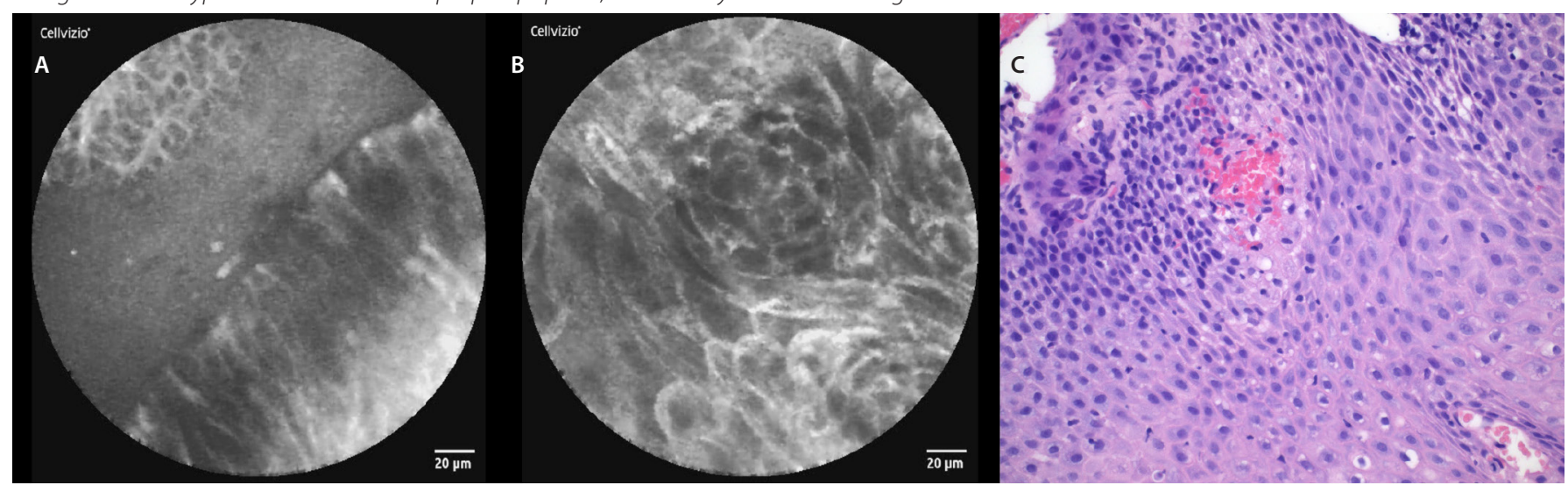


Fig. 5. pCLEview of BE with intestinal metaplasia (nondysplastic): a - columnar cells with dark "goblet" cells, no nuclear atypia, b-columnar cells without nuclear atypia; $\mathrm{C}$ - histopathology examination: columnar epithelium of intestinal type with goblet cells, haematoxylin-eosin staining 40x

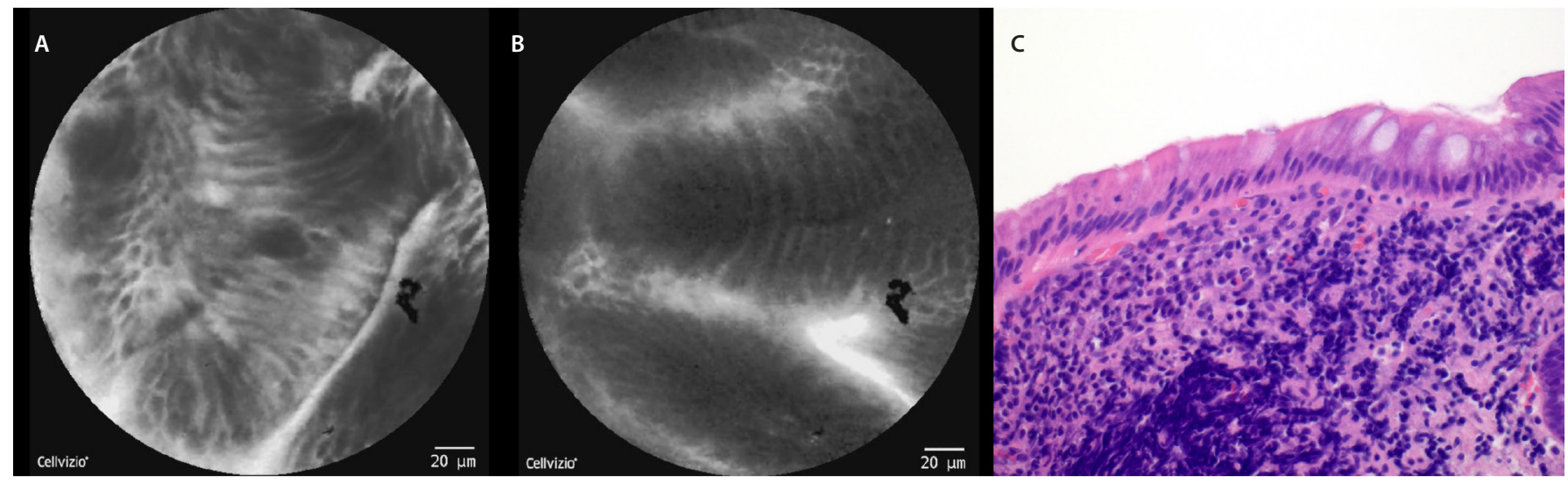

Fig. 6. pCLE view of BE with low grade dysplasia: a - non-round shaped glands with dark columnar cells, b-variable degree of darkness with sharp cutoff of the columnar epithelium; c - histopathology examination: glands with columnar epithelium with lack of goblet cells and nuclear enlargement, haematoxylin-eosin staining $40 x$

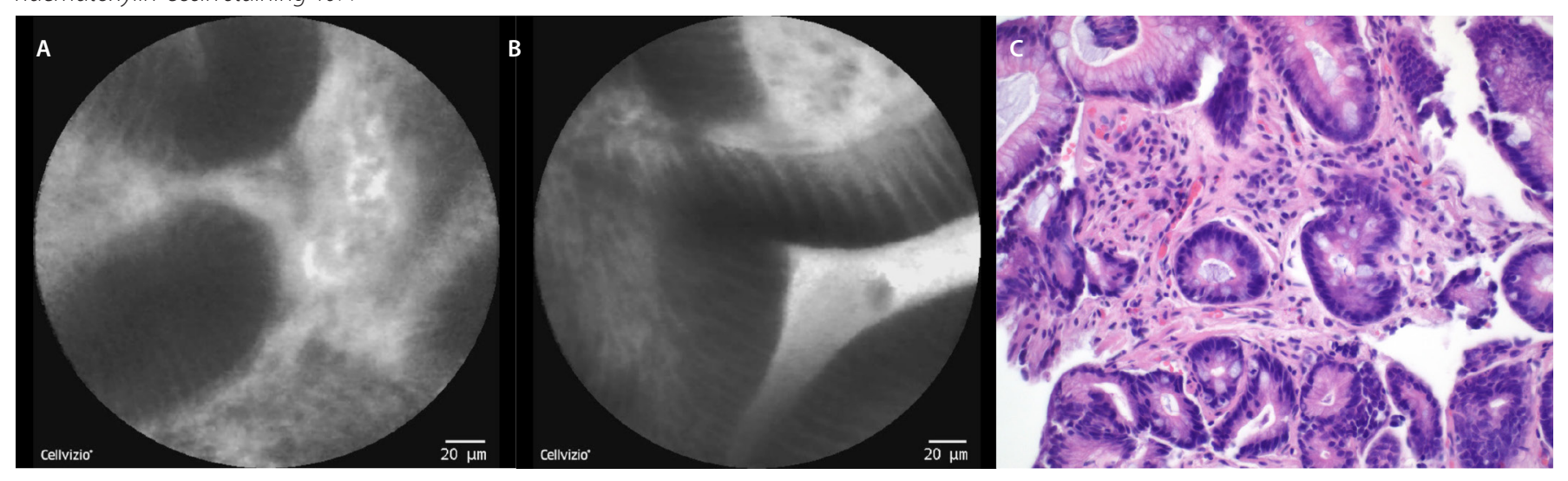

Alongside the possible higher rate of detection of dysplastic BE by $\mathrm{PCLE}$, there are other advantages discussed. The strategy of the Seattle protocol may miss 10-50\% of esophageal neoplasms and the increased risk of bleeding from multiple biopsies is also under debate $(14,15)$. The use of PCLE during endoscopy may increase the detection and targeting of neoplastic lesions and could decrease the number of biopsies (resulting in a lower risk of bleeding) $(12,13,16)$.

The incidence of EAC is increasing and due to late carcinoma detection the 5-year survival rate is low (less than $20 \%)(17,18)$. As well as BE as a complication of gastroesophageal reflux disease, there are other well known risk factors for EAC such as male gender, smoking and obesity (19-21).

Most of the data also considers the location in the distal esophagus on the right side of the wall as risk factor for EAC development. According to this data neoplastic lesions are mainly located between the 12 and 3 o'clock position (22) or by other authors between the 2 and 5 o'clock (23). This part of the distal esophagus should be possibly investigated more carefully if pCLE were to be used.

The length of BE segment is also assessed as a risk factor for EAC progression. The risk of progression increased from $19 \%$ to $28 \%$ for every $1 \mathrm{~cm}$ increase in the length of the $B E(19,24,25)$. Richardson et al (26) in 2018 in his work showed that multiple real-time pCLE can evaluate the entire segment of the BE.
Radiofrequency ablation is an endoscopic ablation technique, and based on the results of several recent studies it is widely used in the eradication of dysplastic BE (without any visible lesion). If visible lesions are apparent, a combination of endoscopic resection and ablation techniques should be performed $(3,6,27-30)$. A future benefit of $\mathrm{PCLE}$ could be the accurate distinguishing between nondysplastic and dysplastic BE and therefore, better therapy management (16).

The risk of lymph node metastases in cases of intramucosal adenocarcinoma (T1a) is low, around 1-2\% (20,31). Therefore endoscopic methods of resection such as endoscopic mucosal resection (the preferred method in case of early EAC) or endoscopic submucosal dissection (in selected cases only) are considered as sufficiently definitive treatment (32). An esophagectomy is mostly seen as a second option due a similar success rate but higher morbidity in treatment. If EAC invades the submucosa (T1b) the risk of lymph node metastases increases to $22 \%$ (some data even shows $46 \%$ ) and for that reason endoscopic resection is not feasible $(31,33,34)$. In cases of EAC (T1b sm1) with favorable grading (well differentiated) and without lymphatic or blood vessel tumor invasion, an endoscopic resection can be considered in patients of a borderline fitness for surgery $(3,30)$.

One possible role of pCLE can be in the accurate definition of the lesions of $B E(L G D, H G D$ or $E A C)$, leading to the best choice of treatment. Dolak et al (2) in 2015 published a study where patients with BE referred 
Fig. 7. pCLEview of esophageal adenocarcinoma: a - disorganized structure, dark columnar cells with severe nuclear atypia (anisokaryosis), b-disorganized structure of the gland with dark columnar cell and dilated irregular vessels; c- histopathology examination: neoplastic glands show highly irregular architectural glandular arrangement and sever nuclear atypia, haematoxylin-eosin staining 40x

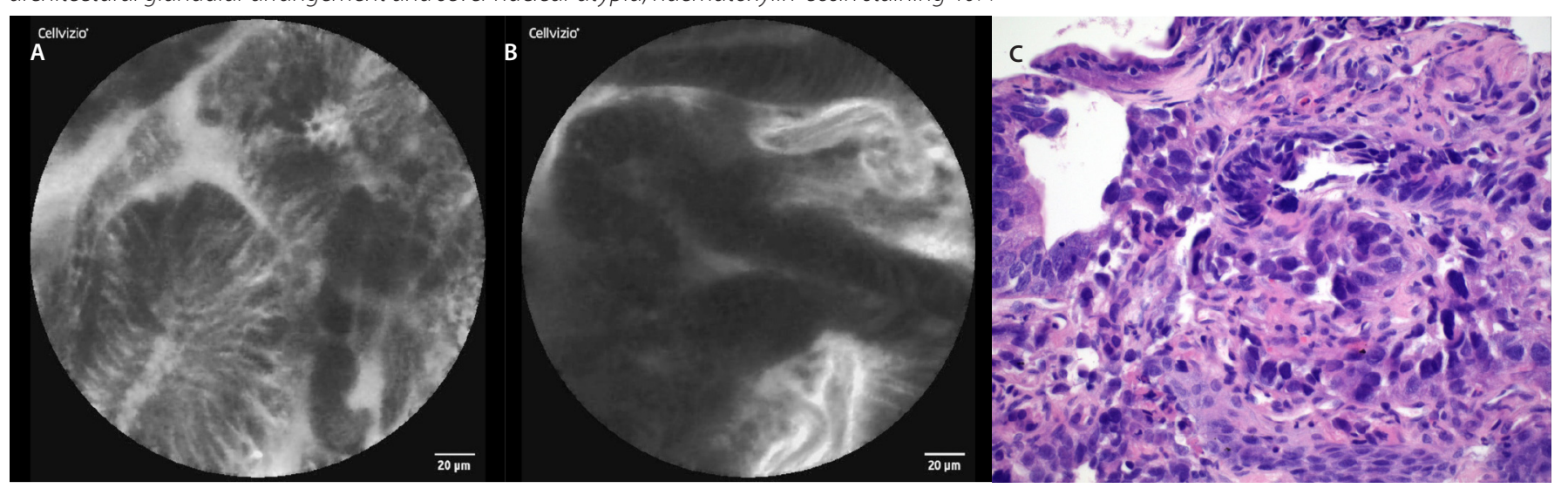

for endoscopic resection were examined by $\mathrm{PCLE}$ before the resection. The study revealed additional neoplastic tissue when compared with the prior HD-WLE and narrow band imaging (NBI).

Promising data is also available from two meta-analyses published in 2016 a 2018, both published by Xiong from China. In 2016 his meta-analysis confirmed that PCLE can be applied to BE surveillance and can lead to the early diagnosis of EAC (35). His recently published analysis from 2018 highlighted significantly increased esophageal neoplasia detection when compared to NBI alone (36).

Performing PCLE in the distal esophagus can sometimes be difficult. However, using a cap at the end of the endoscope can help and improve the stabilization of the probe and the final pCLE image (14). Adverse effects or allergic reactions to the contrast agent Fluorescite ${ }^{\circledast}$ have been studied in 2272 patients (from 16 international centers in total) who underwent pCLE in the gastrointestinal tract. No serious adverse events were reported. Mild adverse events occurred in just $1.4 \%$ of individuals, including nausea/vomiting, transient hypotension without shock, injection site erythema, diffuse rash, and mild epigastric pain (37). In our group we did not record any side effects after the application of the contrast agent. Another relative disadvantage can be the higher purchase price and operational costs. On the other hand, using PCLE during an endoscopy can lead to a decrease in endoscopic procedures and the amount of biopsies taken, potentially reducing the costs $(13,26)$.

As well as PCLE there are other experimental methods currently in development. De Groof et al (38) published a method of computer-aided detection of early BE neoplasia in 2018. This method also enables real-time detection and locates BE neoplasia on endoscopic images with high accuracy. However, more experience, data and further development of the algorithm for the video evaluation performed in this new technique are needed.

\section{REFERENCES}

1. Desai TK, Krishnan K, Samala N et al. The incidence of oesophageal adenocarcinoma in non-dysplastic Barrett's oesophagus: a meta-analysis. Gut 2012; 61: 970-976.

2. Dolak W, Mesteri I, Asari Ret al. A pilot study of the endomicroscopic assessment of tumor extension in Barrett's esophagus-associated neoplasia before endoscopic resection. Endosc Int Open 2015; 3: E19-E28.
A possible limitation of our study is the low number of patients investigated. However, the aim of this pilot study has been to gain experience with pCLE in esophageal diseases and obtain characteristic pCLE figures for future studies.

\section{Conclusion}

Endoscopic detection of neoplasia in BE (especially in long segments) is challenging and advisable in managing surveillance in expert centers for BE.

We studied and established basic PCLE figures for esophageal diseases during a standard cap-assisted endoscopic procedure. It seems to be a possible new technique in BE surveillance and early neoplastic lesion detection. However, more studies and data on larger numbers of patients are needed.

\section{Ethical standard statement}

All procedures which followed were in accordance with the ethical standards of the responsible committee on human experimentation (institutional and national) and with the Helsinki Declaration of 1975, as revised in 2008.

\section{Informed consent}

Informed consent was obtained from all patients for being included in the study.

\section{Conflict of interest}

The authors declare that they have no conflict of interest.

\section{Grants or financial support}

Supported by Ministry of Health, Czech Republic - conceptual development of research organization (FNBr, 65269705, Sup 16/19) and by Ministry of Health of the Czech Republic, grant nr. NU20-03-00126.

3. Weusten B, Bisschops R, Coron E et al. Endoscopic management of Barrett's esophagus: European Society of Gastrointestinal Endoscopy (ESGE) Position Statement. Endoscopy 2017; 49: 191-198.

4. Schölvinck DW, van der Meulen K, Bergman JJGHM et al. Detection of lesions in dysplastic Barrett's esophagus by community and expert endoscopists. Endoscopy 2017; 49: 113-120. 
5. Rastogi A, Puli S, El-Serag HB et al. Incidence of esophageal adenocarcinoma in patients with Barrett's esophagus and high-grade dysplasia: a meta-analysis. Gastrointest Endosc 2008; 67: 394-398.

6. Naini BV, Souza RF, Odze RD Barrett's Esophagus: A Comprehensive and Contemporary Review for Pathologists. Am J Surg Pathol 2016; 40: e45-e66.

7. Wallace M, Lauwers GY, Chen Y et al. Miami classification for probe-based confocal laser endomicroscopy. Endoscopy 2011; 43: 882-891.

8. Gaddam S, Mathur SC, Singh M et al. Novel probe-based confocal laser endomicroscopy criteria and interobserver agreement for the detection of dysplasia in Barrett's esophagus. Am J Gastroenterol 2011; 106: 1961-1969.

9. di Pietro M, Bertani H, O'Donovan M et al. Development and Validation of Confocal Endomicroscopy Diagnostic Criteria for Low-Grade Dysplasia in Barrett's Esophagus. Clin Transl Gastroenterol 2019; 10: e00014.

10. Moravčík P, Hlavsa J, Kunovský L et al. Confocal Laser Endomicroscopy in the Diagnos tics of Malignancy of the Gastrointestinal Tract. Klin Onkol 2017; 30: 258-263.

11. Fuks D, Pierangelo A, Validire P et al. Intraoperative confocal laser endomicroscopy for real-time in vivo tissue characterization during surgical procedures. Surg Endosc 2019; 33: 1544-1552.

12. Sharma P, Meining AR, Coron E et al. Real-time increased detection of neoplastic tissue in Barrett's esophagus with probe-based confocal laser endomicroscopy: final results of an international multicenter, prospective, randomized, controlled trial. Gastrointest Endosc 2011; 74: 465-472.

13. Canto Ml, Anandasabapathy S, Brugge W et al. In vivo endomicroscopy improves detection of Barrett's esophagus-related neoplasia: a multicenter international randomized controlled trial (with video). Gastrointest Endosc 2014; 79: 211-221.

14. Shah T, Lippman R, Kohli D et al. Accuracy of probe-based confocal laser endomicroscopy ( $\mathrm{pCLE}$ ) compared to random biopsies during endoscopic surveillance of Barrett's esophagus. Endosc Int Open 2018; 6: E414-E420.

15. Kariv R, Plesec TP, Goldblum JR et al. The Seattle protocol does not more reliably predict the detection of cancer at the time of esophagectomy than a less intensive surveillance protocol. Clin Gastroenterol Hepatol 2009; 7: 653-658.

16. Caillol F, Godat S, Poizat F et al. Probe confocal laser endomicroscopy in the therapeutic endoscopic management of Barrett's dysplasia. Ann Gastroenterol 2017 30: $295-301$

17. Siegel R, Naishadham D, Jemal A Cancer statistics, 2012 CA Cancer J Clin 2012; 62: 10-29. 18. Hur C, Miller M, Kong CY et al. Trends in esophageal adenocarcinoma incidence and mortality. Cancer 2013; 119: 1149-1158.

19. Falk GW Barrett's Esophagus: Frequency and Prediction of Dysplasia and Cancer. Best Pract Res Clin Gastroenterol 2015; 29: 125-138

20. Domper Arnal MJ, Ferrández Arenas Á, Lanas Arbeloa Á Esophageal cancer: Risk factors, screening and endoscopic treatment in Western and Eastern countries. World J Gastroenterol 2015; 21: 7933-7943.

21. Svoboda P, Dítě P, Klvaňa P et al. Risk factors and progression predictors of Barrett's oesophagus to adenocarcinoma. Vnitř Lék 2014; 60: 467-473.
22. Pech $\mathrm{O}$, Gossner L, Manner $\mathrm{H}$ et al. Prospective evaluation of the macroscopic types and location of early Barrett's neoplasia in 380 lesions. Endoscopy 2007; 39: 588-593.

23. Kariyawasam VC, Bourke MJ, Hourigan LF et al. Circumferential location predicts the risk of high-grade dysplasia and early adenocarcinoma in short-segment Barrett's esophagus. Gastrointest Endosc 2012; 75: 938-944.

24. Pohl H, Wrobel K, Bojarski C et al. Risk factors in the development of esophageal adenocarcinoma. Am J Gastroenterol 2013; 108: 200-207.

25. Anaparthy R, Gaddam S, Kanakadandi V et al. Association between length of Barrett's esophagus and risk of high-grade dysplasia or adenocarcinoma in patients without dysplasia. Clin Gastroenterol Hepatol 2013; 11: 1430-1436.

26. Richardson C, Colavita P, Dunst C et al. Real-time diagnosis of Barrett's esophagus: a prospective, multicenter study comparing confocal laser endomicroscopy with conventional histology for the identification of intestinal metaplasia in new users. Surg Endosc 2019; 33: 1585-1591.

27. Fitzgerald RC, di Pietro M, Ragunath K et al. British Society of Gastroenterology guidelines on the diagnosis and management of Barrett's oesophagus. Gut 2014; 63: 7-42.

28. Shaheen NJ, Sharma P, Overholt BF et al. Radiofrequency ablation in Barrett's esophagus with dysplasia. N Engl J Med 2009; 360: 2277-2288.

29. Kroupa R, Konečný Š, Dolina J Current trends in the diagnosis and treatment of gastroesophageal reflux disease. Vnitř Lék 2018; 64: 588-594.

30. Martínek J, Falt P, Gregar J et al. Guidelines of the Czech gastroenterological society -endoscopic treatment of Barrett's esophagus and early esophageal neoplasia. Gastroent Hepatol 2013; 67: 479-487.

31. Leers JM, DeMeester SR, Oezcelik A et al. The prevalence of lymph node metastases in patients with $\mathrm{T1}$ esophageal adenocarcinoma a retrospective review of esophagectomy specimens. Ann Surg 2011; 253: 271-278.

32. Pimentel-Nunes P, Dinis-Ribeiro M, Ponchon T et al. Endoscopic submucosal dissection: European Society of Gastrointestinal Endoscopy (ESGE) Guideline. Endoscopy 2015; 47: 829-854. 33. Lin JL T1 esophageal cancer, request an endoscopic mucosal resection (EMR) for in-depth review. J Thorac Dis 2013; 5: 353-356.

34. Barbour AP, Jones M, Brown I et al. Risk stratification for early esophageal adenocarcinoma: analysis of lymphatic spread and prognostic factors. Ann Surg Oncol 2010; 17: 2494-2502.

35. Xiong YQ, Ma SJ, Zhou JH et al. A meta-analysis of confocal laser endomicroscopy for the detection of neoplasia in patients with Barrett's esophagus. J Gastroenterol Hepatol 2016; 31: 1102-1110.

36. Xiong YQ, Ma SJ, Hu HY et al. Comparison of narrow-band imaging and confocal laser endomicroscopy for the detection of neoplasia in Barrett's esophagus: A meta-analysis. Clin Res Hepatol Gastroenterol 2018; 42: 31-39.

37. Wallace MB, Meining A, Canto Ml et al. The safety of intravenous fluorescein for confocal laser endomicroscopy in the gastrointestinal tract. Aliment Pharmacol Ther 2010; 31: 548-552. 38. Groof J de, van der Sommen F, van der Putten J et al. The Argos project: The development of a computer-aided detection system to improve detection of Barrett's neoplasia on white light endoscopy. United Eur Gastroenterol J 2019; 7: 538-547. 